\title{
A systematic review on the aboveground biomass and carbon stocks of Indian forest ecosystems
}

\author{
Onkar Salunkhe* ${ }^{*}$, P. K. Khare, Richa Kumari and M. L. Khan
}

\begin{abstract}
Background: Tropical forests play a crucial role as source and sink in global carbon cycle. Development and other anthropogenic activities have led to degradation of forest land, and ultimately, it results in loss of biodiversity and increases concentration of $\mathrm{CO}_{2}$ in atmospheres. Therefore, there is urgent need to estimate regional and national level carbon stock for making forest-based policies and strategies for mitigation of $\mathrm{CO}_{2}$. Patchy and sporadic information is available on biomass and carbon stock of Indian forests. The paper presents a systematic review and comprehensive account of studies conducted in different forest types in India.

Result: There are six major forest types found in India consisting of 15 groups and other subgroups with peculiar characteristics. Methodologies used by researchers for biomass/carbon stock estimation are destructive, nondestructive, tree inventories data, species-specific biomass estimation, and remote sensing. Majority of estimates are based on nondestructive allometric equation approach. Studies showed positive correlation between tree species, diameter at breast height, and biomass/carbon stock. Small- and medium-sized growing trees, invasive species, mixed forest, Agroforestry, and Agrosilviculture also play an important role in atmospheric carbon assimilation. The results of diverse forest carbon stock studies are broadly categorized in North, Central, and Southern India. Present review will be helpful for developing conservation policies and decision to increase carbon stock and also REDD+ program for particular forest ecosystem.

Conclusion: The systematic literature review was carried out to gather and summarize information from different studies conducted on forest ecosystems and quantification methods used for biomass estimation and carbon stock in different forests types and states of India. In general, great variability occurs in aboveground biomass and carbon stock on account of climatic and geographic differences. To obtain good and accurate estimations, following nondestructive approach, species-specific density-based equations are required from different habitats and also in relation to degradation status of forests. As such regional volume equations would increase error of estimations. The comprehensive account of data would be helpful to formulate strategies based on carbon sequestration in Indian forests for $\mathrm{CO}_{2}$ mitigation.
\end{abstract}

Keywords: Tropical forests, Aboveground biomass, Carbon stock

\footnotetext{
* Correspondence: onkarsalunkhe@yahoo.com

Laboratory of Ecology, Department of Botany, Dr. Hari Singh Gour University,

Sagar, Madhya Pradesh 470 003, India
} 


\section{Background}

Forest ecosystems act as source and sink of atmospheric carbon dioxide $\left(\mathrm{CO}_{2}\right)$ and are one of the most faithful options for carbon sequestration and play a crucial role in regulating global carbon cycle. Local, regional, and national carbon inventories of source and sinks of carbon are indispensable to assess the prospective role of various carbon sequestration pools for reducing atmospheric $\mathrm{CO}_{2}$ accumulation, and therefore it is a pioneer step for preventing global warming. The studies also important for developing of systems/markets for national and international carbon credit/emission trading as well as in reducing emission from deforestation and forest degradation (REDD+) programs in developing countries (Han et al. 2007; NEFA 2002; Kale et al. 2004).

Article 2.1 of Kyoto Protocol addresses the issues related to global warming and asked to own responsibility to signatory countries to protect the sinks and reservoirs of greenhouse gases and increase afforestation, reforestation, and promote sustainable forest management (Yavaşli 2012). India is also one of the signatory in Kyoto Protocol; hence, various studies have been carried out at different parts of the country. However, the data is patchy and sporadic.

Precise assessment of $\mathrm{CO}_{2}$ emissions as a result of land use changes, forest fire, degradation, and other anthropogenic activities are a few challenging issues for understanding global carbon cycle and hence for making policies. Therefore, recent researches mainly focus on biomass assessment to trim down uncertainties related to carbon cycle and emissions. Understanding of spatial distribution of biomass is a prerequisite to find out the sources and sinks of carbon (C) as a result of forest to degraded land and vice versa as well as their temporal variations (Yavaşli 2012).

Forests play a vital role in global carbon flux and act as carbon sink by storing large quantities of carbon for a long period of time. This storage of organic matter in biomass provides a lag for complete carbon emission on account of respiration. More than $40 \%$ of the global primary production in forest ecosystem is accomplished by tropical and subtropical forests (Beer et al. 2010). India is eighth among the top 10 most biodiverse countries (Butler 2016), with $21.05 \%\left(692,027 \mathrm{~km}^{2}\right)$ of its geographical area $\left(3,287,263 \mathrm{~km}^{2}\right)$ under forest and tree cover (FSI 2011). Near about 173,000 villages are classified as forest fringe villages, and their dependency on forest resources is obviously large. Hence, it is very much important to assess the likely impact of forest degradation on projected climate change. In view of this, carbon/biomass stock studies play a crucial role in relation to develop and implement adaptation policies for both biodiversity conservation, protection, future sustainable utilization of forest resources, safeguarding the livelihoods of forest- dependent people, and reducing pressure on forest ecosystems (Kishwan et al. 2009).

According to fourth Assessment Report of the Intergovernmental Panel on Climate Change (IPCC 2007), limited information is available regarding the biomass, carbon stock/sequestration at national and regional level. This is particularly true for India as a few and sporadic forest biomass/carbon studies are available for carbon dioxide mitigation assessment (Ravindranath and Ostwald 2008). Another shortcoming is that, these estimates of carbon sequestration potential and stock are done without taking consideration of regional variations in species distribution, growth rates, and carbon sequestration rates. Nevertheless, such estimates are useful in formulating strategies for reducing $\mathrm{CO}_{2}$ emissions with the help of REDD+ in global climate negotiations as a mitigation option (Gibbs et al. 2007; Murthy et al. 2012). Unrestricted utilization of forest resources, rapid population growth, and industrial development are manifested in land use changes, thereby reducing the extent and area of forests particularly in tropical countries like India.

A large number of vegetation/forest types occur in India due to immense climatic and edaphic variations. Therefore, all possible forest types ranging from alpine to very dry forests are occurring at different places. In view of the above variability, comprehensive data on biomass and carbon stocks are lacking at local, regional, and national level as required for millennium ecosystem assessment (MEA 2005) to workout strategies and policies for mitigating atmospheric $\mathrm{CO}_{2}$ through organizing and conserving different forest vegetations.

The present review paper aims to evaluate forest ecosystems and forest types in relation to quantification methods and biomass estimates in India. Carbon stocks in different forest types are also evaluated based on studies available: information from various earlier studies with the help of systematic review papers, research papers, scientific reports, government policy reports available online or published literature for implementation of REDD+ policies.

Biomass and carbon studies in Indian forest ecosystem are quite challenging on account of varying localities and difficulties in accessibilities. No systematic data is available on studies on biomass/carbon of different regions and types of forests and uniform estimation methodology of Indian forests at one place. Although, a number of studies have been carried out on biomass/carbon stock estimations in India, they are sporadic and patchy in relation to particular forest ecosystem and methodology. The aim of the present paper is also to furnish comprehensive account of forest types, quantification methods used for biomass estimation, and biomass stock in different forest ecosystems in India. 


\section{Methods}

In order to review and procure information from existing research on types of forest, basal area, biomass/carbon stock, sequestration pool in different forest ecosystems of India, a literature search was carried out during January 2017 to August 2017 using Web of Science (or Web of Knowledge), Google Scholar Citation, ResearchGate, offline journals, book chapters, Indian government scientific reports, Forest Survey of India data, Botanical Survey of India data, as well as reports published by Indian Ministry of Environment, Forest and Climate Change. The objective is limited to only Indian forest ecosystem in relation to biomass/carbon studies.

The methodology followed for search of literature consists of (a) generation of keywords as biomass/carbon stock, sequestration or pool estimation in different states in India, destructive methodology, nondestructive, allometric equations for biomass/carbon estimation in India for plantation forest, natural forest, Agroforestry, shrub biomass, types of forest, and their biomass status. (b) Search for literature on online using various sites (Google scholar citation, Web of science or knowledge, journal's sites), offline journals and book chapters from libraries of forest institutes of India, government policies and reports downloaded from websites. (c) Collection of main findings and highlighting them in review (d) interpretation of highlighted findings.

To collect more and more research articles for focusing biomass in Indian forest ecosystems, we also add or used positive, negative correlations between basal area and biomass, species diversity, species wise biomass/carbon estimation. The objective was to find most suitable or relevant published data for various Indian states and types of Indian forests. We also collected cross-references research articles which are relevant to our study. In all, 101 critical research articles were found meeting the aims and objective of study. Since the studies pertaining to the aims of the present paper are sporadic and not all the aspects are included in different papers available for Indian forest ecosystems, at places data are deficient and given as such. Main emphasis is given for biomass and carbon stocks in different forest types, e.g., tropical, temperate, alpine, and coniferous forests from Himalayan region.

It is worth to reveal that this study principally highlight the recent state of knowledge with the help of literature review instead of focusing on any data analysis or any statistical information. However, we used display data from all collected research articles whose references have been cited in the present paper.

\section{Results and discussion}

Types of forest in India

According to Champion and Seth (1968), there are six major forest types found in India which contain 15 groups and other subgroups with peculiar characteristic features, and all forests subgroups contained varying species composition (Table 1). This is the most exhaustive classification for forests in India that includes almost all climatic, edaphic, and successional vegetations.

\section{Methods employed for estimation of aboveground biomass}

In natural forest ecosystems, accumulated biomass is an important parameter for assessing sustainable utilization, productivity, and $\mathrm{CO}_{2}$ sequestration from the atmosphere. Therefore, accuracy of estimation method is very important for a number of applications like global carbon cycle, timber extraction, to assess carbon stock tracking changes, etc. (Vashum and Jayakumar 2012). The aboveground forest biomass/carbon have been estimated by a number of methods and techniques based on inventory and stock tables. Most of the studies have been done in tropical forests with varying interests and objectives such as nutrient cycling, productivity, and sustainability of forest. The data is collected from limited to small, nonrandomly selected areas with insufficient focus on global carbon research (Brown et al. 1989). Most of the tropical tree inventories included large girth class trees with an interest in commercial timber. Further, the tropical forests are uneven aged and composed of all size and age classes. Omission of small or smaller girth class trees would many a times underestimate the important role of these individuals to the total forest biomass. Therefore, it is imperative to first analyze the structure and species composition of the vegetation and consider all or at least large proportion of the vegetation component for biomass estimation especially in tropical forests (Salunkhe et al. 2016).

There is no robust method developed for accurate biomass estimation. Existing methods are having controversies with variable accuracy ranges. Various methods are employed for measuring biomass/carbon include destructive (total harvesting of sample), nondestructive (measurable parameters like basal area, height, tree density), tree inventories data, species-specific biomass estimation, and remote sensing methods (Brown et al. 1989, 1999; Lu 2006; Murali et al. 2005). Absolute measurements of biomass can be taken up only at the time of felling which is not possible in all situations (Murali et al. 2005). Measurements for basal area, height, and species-specific gravity in field are good criteria for estimating biomass as nondestructive methods (de Gier 2003). In India, the selection system for felling is followed where only the marked trees are taken out leaving behind the immature/unmarked trees.

Field measurement method could be categorized into two type, viz., destructive and nondestructive biomass estimation methods. Destructive method is also popularly 
Table 1 Major forests groups of Indian forest and their area

\begin{tabular}{|c|c|c|c|}
\hline Major group & Group & Area (mha) & $\%$ Area \\
\hline \multirow[t]{4}{*}{ I. Moist tropical forest } & 1. Tropical wet-evergreen forest & 4.5 & 5.8 \\
\hline & 2. Tropical semi-evergreen forest & 1.9 & 2.5 \\
\hline & 3. Tropical moist deciduous forest & 23.3 & 30.3 \\
\hline & 4. Littoral and swamp forest & 0.7 & 0.9 \\
\hline \multirow[t]{3}{*}{ II. Dry tropical forest } & 5. Tropical dry deciduous forest & 29.4 & 38.2 \\
\hline & 6. Tropical thorn forest & 5.2 & 6.7 \\
\hline & 7. Tropical dry evergreen forest & 0.1 & 0.1 \\
\hline \multirow[t]{3}{*}{ III. Montane subtropical forest } & 8. Subtropical broad-leaved hill forest & 0.3 & 0.4 \\
\hline & 9. Subtropical pine forest & 3.7 & 5.0 \\
\hline & 10. Subtropical dry evergreen forest & 0.2 & 0.2 \\
\hline \multirow[t]{3}{*}{ IV. Montane temperate forest } & 11. Montane wet temperate forest & 1.6 & 2.0 \\
\hline & 12. Himalayan moist temperate forest & 2.6 & 3.4 \\
\hline & 13. Himalayan dry temperate forest & 0.2 & 0.2 \\
\hline V. Subalpine forest & 14. Subalpine forest & - & - \\
\hline VI. Alpine Scrub & 15. Moist - alpine scrub & 3.3 & 4.3 \\
\hline
\end{tabular}

Based on Champion and Seth (1968)

known as harvest method which is direct method for estimation aboveground biomass (AGB) and carbon stock (Gibbs et al. 2007). This method comprises of harvesting or felling of trees in a given area followed by weighing of different components harvested like trunk, leaves, branches, etc. (Nelson et al. 1999; Hashimotio et al. 2000; Lodhiyal and Lodhiyal 2003; Chung-Wang and Ceulemans 2004; Ravindranath and Ostwald 2008; Devi and Yadava 2009). This method is unwieldy and could only be applied to small area and not applicable to degraded forest and threatened forest species (Montès et al. 2000). Nevertheless, it is used to develop biomass estimation equations for assessing large-scale biomass (Navár 2009; Segura and Kanninen 2005).

Another method of field measurement is nondestructive approach. Taking measurable parameters, like girth at breast height $(\mathrm{GBH})$, tree height, tree volume, and density of wood (Ravindranath and Ostwald 2008), and with the help of allometric equation (general or species specific), biomass is calculated (Brown et al. 1989; Nowak 1993; Hughes et al. 1999). With the help of forest inventories data, allometric equations are developed for assessing the biomass and carbon sequestration in forest ecosystem (Nelson et al. 1999; Chung-Wang and Ceulemans 2004; Montès et al. 2000; Navár 2009; Brown et al. 1989; Basuk et al. 2009). These equations are developed for single or mixture of species for comparisons of biomass estimations (Vashum and Jayakumar 2012).

Another method for biomass estimation is remote sensing and geographical information system (GIS). To estimate forest biomass, several studies have been conducted using remote sensing technology (Drake et al.
2003; Baccini et al. 2004; Anaya et al. 2009). However, for validation, data is required from field. The tree allometric equations appear more accurate in terms of selecting trees from the same species as well as growing in the same climate and soil environment in terms of their application (Clark and Clark 2000).

\section{Indian forest ecosystem biomass/carbon estimates}

The phytomass and carbon pool of Indian forest for the years 1880 to 1980 was calculated by Richards and Flint (1994) with the help of historical records, ecological data, and population-based forest biomass degradation model. Hingane (1991) used ecological studies-based mean phytomass density for estimation of carbon in two forest types. Using FAO inventories for ecological zonewise five catogaries, Dadhwal et al. (1998) calculated phytomass carbon pool of 1980 and 1990 of Indian forests. Studies have been summarized in Table 2.

Manhas et al. (2006) reported the India's total carbon stock as 1085.06 and $1083.69 \mathrm{Mt}$ in 1984 and 1994, respectively. The major forests contributed to carbon stock were of the order of: Miscellaneous forest $>$ Shorea robusta forest $>$ Tectona grandis forest $>$ Temperate forest $>$ Tropical forest > Bamboo forest, etc. Chhabra et al. (2002a, b) calculated total standing biomass (above and below ground) using biomass expansion factors. Their results showed that total biomass was $8683.7 \mathrm{Mt}$, that is, aboveground (6865.1 Mt) and belowground biomass (1818.7 Mt) contributed $79 \%$ and $21 \%$ to the total biomass, respectively, with mean biomass density of Indian forest as $135.6 \mathrm{t} \mathrm{h}^{-1}$. From studies on carbon budget of the Indian forest ecosystems, Haripriya (2003) concluded 
Table 2 Carbon pool estimates of Indian forest

\begin{tabular}{|c|c|c|c|c|}
\hline Year & Forest area (M ha) & Methodology & $\begin{array}{l}\text { Phytomass carbon } \\
\text { pool ( } \operatorname{Tg} C)\end{array}$ & Source \\
\hline 1880/1980 & $102.7 / 64.6$ & $\begin{array}{l}\text { Historical records, ecological data and population-based } \\
\text { forest biomass degradation model }\end{array}$ & $7940 / 3426$ & Richards and Flint (1994) \\
\hline 1980 & 52.6 & $\begin{array}{l}\text { Ecological studies-based mean phytomass density for } \\
\text { two forest types }\end{array}$ & 2587 & Hingane (1991) \\
\hline 1980/1990 & 51.73 & $\begin{array}{l}\text { Using FAO inventories for ecological zone-wise five } \\
\text { categories }\end{array}$ & $3322 / 3117$ & Dadhwal et al. (1998) \\
\hline 1982/1991 & $64.2 / 64.01$ & $\begin{array}{l}\text { State-wise RS-based forest area, field inventories based } \\
\text { growing stock and crown density based BEFs for two classes }\end{array}$ & $3978 / 4071$ & Dadhwal and Shah (1997) \\
\hline 1985 & 64.2 & Growing stock volume data and single conversion factor & 1994 & Dadhwal and Nayak (1993) \\
\hline 1986 & 64.01 & $\begin{array}{l}\text { RS-based area, crown cover fraction for } 16 \text { forest types, } \\
\text { Phytomass densities from ecological studies }\end{array}$ & 4179 & Ravindranath et al. (1997) \\
\hline 1993 & 64.01 & $\begin{array}{l}\text { State-wise growing stock FSI data, BEFs as function of GSVD } \\
\text { for three crown density classes, four forest categories }\end{array}$ & 4341.8 & Chhabra et al. (2002a, b) \\
\hline 1995 & 63.96 & $\begin{array}{l}\text { Forest stratum-wise growing stock volume FSI data and a } \\
\text { standard BEF relating to wood volume by IPCC }\end{array}$ & 2026 & Lal and Singh (2000) \\
\hline
\end{tabular}

Procured from: Chhabra et al. (2002b)

Mha $10^{6}$ ha, $\operatorname{TgC} 10^{12} \mathrm{gC}$, BEF biomass expansion factor, FSI forest survey of India, GSVD growing stock volume density, IPCC Intergovernmental Panel on Climate Change, $R S$ remote sensing

that the Indian forest sector acted as a source of $12.8 \mathrm{Tg} C$ for the year 1994. Estimated carbon pool size of trees and forests in India ranged from 41 to $48 \mathrm{Mg} \mathrm{Cha}^{-1}$ and from

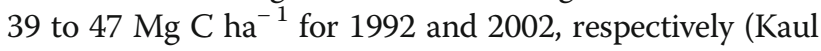
et al. 2011). Sheikh et al. (2011) estimated India's forest biomass and reported variations from 3325 to $3161 \mathrm{Mt}$ for year 2003 to 2007, respectively. Net fluxes of $\mathrm{CO}_{2}$ were $372 \mathrm{Mt}$ and $288 \mathrm{Mt}$ in I assessment and for II assessment period with annual emission of 186 and $114 \mathrm{Mt}$ of $\mathrm{CO}_{2}$, respectively.

For selected plantation forest of India, estimated rate of carbon flux was addressed by Raizada et al. (2003). Different species and their total carbon flux in planted area are summarized in Table 3. Important highlights of study are:
1. Short rotation planted forests having regular leaf shading patterns possess more capacity for carbon sequestration in litter.

2. Slow decomposing litter was produced by fast growing conifers leading to decline in ground flora as well as productivity with risk for fire damage.

3. As compared to mono culture, exotic and native species mixed plantation could be more efficient in carbon sequestration.

4. For wasteland afforestation and reforestation, fast growing hardy species like Eucalyptus would be ideal choice, and for the agrisilvicultural practices, soft woody species would be more ideal in plain areas.

Table 3 Estimated rate of carbon flux in selected planted forests in India

\begin{tabular}{|c|c|c|c|c|}
\hline Tree species & $\begin{array}{l}\text { Area (ha) } \\
\text { (FSI 1999) }\end{array}$ & $\begin{array}{l}\text { Av. litter production } \\
\left(\mathrm{t} \mathrm{ha}^{-1} \mathrm{yr}^{-1}\right)\end{array}$ & $\begin{array}{l}\text { C flux } \\
\left(\text { Mt } C y^{-1} .^{-1}\right)\end{array}$ & Total $\mathrm{C}$ flux in the planted area (Mt. C yr. ${ }^{-1}$ ) \\
\hline Eucalyptus spp. & 1360.91 & 4.50 & 2.03 & 27.5 \\
\hline Tectona grandis & 1330.09 & 3.60 & 1.62 & 21.5 \\
\hline Acacia auriculiformis & 564.67 & 3.03 & 1.36 & 7.7 \\
\hline Pinus roxburghii & 381.54 & 4.94 & 2.22 & 7.1 \\
\hline Dalbergia sisoo & 266.58 & 3.03 & 1.36 & 3.6 \\
\hline Shorea robusta & 250.28 & 11.27 & 5.07 & 1.3 \\
\hline Gmelina arborea & 148.01 & 2.17 & 0.97 & 1.4 \\
\hline Casuarina equisetifolia & 134.00 & 3.15 & 1.41 & 1.9 \\
\hline Populus deltoids & 47.48 & 3.71 & 1.66 & 0.8 \\
\hline Bombax ceiba & 37.97 & 1.30 & 0.58 & 0.2 \\
\hline
\end{tabular}

Raizada et al. (2003) 
For rubber (Hevea braziliensis) plantation forest, Day (2005) estimated average carbon stock in North-Eastern states of India (Table 4). Results indicate that an average carbon store in rubber plantation is around $136 \mathrm{t} \mathrm{c} \mathrm{ha}^{-1}$ out of which $92.7 \mathrm{t} \mathrm{c} \mathrm{ha}^{-1}$ is contributed by soil and addition $2.40 \mathrm{t} \mathrm{c} \mathrm{ha}^{-1}$ through litter fall and undergrowth vegetation. Also about $7 \mathrm{Mt}$ carbon remain stored in rubber plantation (area 51,510 ha in 2002-2003).

For the tropical dry forest ecosystem of India, the allocation of plant biomass $\left(\mathrm{t} \mathrm{ha}^{-1}\right)$ in different components is given in Table 5 .

A comprehensive account of standing biomass for different forest types of India was given by Ravindranath et al. (1997) (Table 6).

\section{Other sporadic studies of biomass/carbon estimation from different parts of India}

These studies are broadly categorized under North, Central, and Southern forest ecosystem of India.

North Indian forest ecosystem biomass/carbon estimation Forest of Himachal Pradesh in Himalayan range had $1158 \mathrm{t} \mathrm{ha}^{-1}$ as mean AGB (Sharma et al. 2008). Devi and Yadava (2009) carried out study for estimation of $A G B$ and net primary productivity of semi-evergreen tropical forest of Manipur, North Eastern India, following harvest method. A positive correlation between tree species, DBH, and AGB of trees was also reported. In Garhwal Himalaya of Uttrakhand, the total live tree biomass density ranged from 215.5 to $486.2 \mathrm{Mg} \mathrm{ha}^{-1}$ and live $\mathrm{C}$ density varied from 107.8 to $234.1 \mathrm{Mg} \mathrm{C}$ ha $^{-1}$ (Gairola et al. 2011). The total biomass carbon pool production of an old growth Pinus kesiya Royle ex Gordon forest in North Eastern India was $460.5 \mathrm{Mg} \mathrm{ha}^{-1}$ of which $91.20 \%$ was AGB and $8.8 \%$ below ground biomass. Out of total biomass, $77 \%$ contribution was that of P. kesiya, $13.5 \%$ of broad-leaved tree species, $0.12 \%$ of shrub, $0.03 \%$ of herb, and $0.5 \%$ of litter (Baishya and Barik 2011).
According to Sharma et al. (2011), carbon stock on different slope aspects in seven major forest types of temperate region of Garhwal Himalaya ranged from 77 . $3 \mathrm{C} \mathrm{Mg} \mathrm{ha}^{-1}$ on South-East aspect to $291.6 \mathrm{C} \mathrm{Mg} \mathrm{ha}^{-1}$ on North-East aspect with total carbon density of 118 . $1 \mathrm{C} \mathrm{Mg} \mathrm{ha}^{-1}$ and 469.1 $\mathrm{C} \mathrm{Mg} \mathrm{ha}^{-1}$. At high-altitude forests of central Himalayan region, Verma et al. (2012) assessed the carbon storage capacity of Quercus semecarpifolia. These forests had carbon ranging between 210.26 and $258.02 \mathrm{t} \mathrm{ha}^{-1}$ in their biomass in 2009 and mean carbon sequestration rate between 3.7 and $4.8 \mathrm{t} \mathrm{ha}^{-1} \mathrm{yr}^{-1}$, respectively.

In sacred forest of Tehri of Garhwal Himalaya, Uttarakhand, biomass and total carbon density of different species based on nondestructive method were $1549.704 \mathrm{Mg} \mathrm{ha}^{-1}$ and $774.77 \mathrm{Mg} \mathrm{ha}^{-1}$, respectively. Maximum biomass and carbon density was recorded in Pinus wallichiana (Pala et al. 2013). According to Borah et al. (2013) in the Cachar district of Assam, Northeast India, aboveground biomass ranged from $32.47 \mathrm{Mg} \mathrm{ha}^{-1}$ to $261.64 \mathrm{Mg} \mathrm{ha}^{-1}$ and carbon stock ranged from $16.24 \mathrm{Mg} \mathrm{ha}{ }^{-1}$ to 130 . $82 \mathrm{Mg} \mathrm{ha}^{-1}$, respectively. Interestingly, small to medium trees contributed more aboveground biomass and carbon stock as compared to large trees. Nautiyal and Singh (2013) estimated carbon stock potential of Oak and Pine forests in Garhwal region of Central Himalayas. Total carbon density estimates were $2420.54 \mathrm{Mg} \mathrm{ha}^{-1}$ for Oak and $986.93 \mathrm{Mg} \mathrm{ha}^{-1}$ for Pine forests.

Giri et al. (2014) made assessment of biomass and carbon stock in Tectona grandis plantation in Dehradun forest division. The whole ecosystem biomass was $218.22 \mathrm{t} \mathrm{ha}{ }^{-1}$ of which Tectona grandis contributed $147.50 \mathrm{t} \mathrm{ha}^{-1}$, five associated species as $65.62 \mathrm{t} \mathrm{ha}^{1}$, and shrub and herb species as 2.218 and $0.773 \mathrm{t} \mathrm{ha}{ }^{-1}$. At Srinagar hydroelectric project, Uttarakhand, the total tree carbon density ranged in between $273.39 \mathrm{t} \mathrm{ha}^{-1}$ and $94.38 \mathrm{t} \mathrm{ha}^{-1}$. Arora et al. (2014) estimated AGB and C stock in an age series of Populus deltoides plantation at Tarai region of central

Table 4 Carbon sequestration ( $\mathrm{t} \mathrm{ha}^{-1}$ ) by planted forest of rubber in North Eastern India

\begin{tabular}{|c|c|c|c|c|c|}
\hline \multirow[t]{2}{*}{ State } & \multirow[t]{2}{*}{ Rubber planted forest area in 2002-2003 (ha) } & \multicolumn{2}{|c|}{ Carbon store rubber } & \multirow[t]{2}{*}{ Annual $\mathrm{C}$ addition from under growth } & \multirow[t]{2}{*}{ Total carbon } \\
\hline & & Plant & Soil & & \\
\hline Tripura & 28,853 & 1762.9 & 1915.8 & 69.2 & 3747.9 \\
\hline Assam & 13,208 & 807.0 & 919.2 & 31.7 & 1757.9 \\
\hline Meghalaya & 4586 & 280.2 & 451.2 & 11.0 & 742.4 \\
\hline Nagaland & 2087 & 127.5 & 225.4 & 5.0 & 357.9 \\
\hline Manipur & 1708 & 104.3 & 102.4 & 4.1 & 210.8 \\
\hline Mizoram & 696 & 42.5 & 62.4 & 1.7 & 106.6 \\
\hline Arunachal Pradesh & 372 & 22.7 & 58.4 & 8.9 & 90.0 \\
\hline Entire North East & 51,510 & 3147.1 & 3734.8 & 131.6 & 7013.5 \\
\hline
\end{tabular}

Day (2005) 
Table 5 Allocation of plant biomass $\left(\mathrm{t} \mathrm{ha}^{-1}\right)$ in different components of tropical dry forest of India

\begin{tabular}{|c|c|c|c|c|}
\hline \multirow[t]{2}{*}{ Locality } & \multicolumn{3}{|c|}{ Plant biomass } & \multirow[t]{2}{*}{ Source } \\
\hline & $\overline{A G}$ & BG & Total & \\
\hline Varanasi & - & 7.6 & - & Bandhu (1970) \\
\hline Varanasi & 205.5 & 34.3 & 239.8 & Singh (1975) \\
\hline Udaipur & 28.2 & - & - & Ranawat and Vyas (1975) \\
\hline Dehra Dun & 129.6 & - & - & Kaul et al. (1979) \\
\hline Varanasi & 64.3 & 9.5 & 78.3 & Singh and Singh (1981) \\
\hline Chandraprabha & 95.0 & - & - & Singh (1989) \\
\hline Tripura & 114 & 24.40 & 138.6 & Negi et al. (1990) \\
\hline Coimbatore & 27.6 & 11.1 & 38.6 & George et al. (1990) \\
\hline Haldwani & $74.6-164.0$ & $15.4-17.9$ & $90.0-181.9$ & Negi et al. (1995) \\
\hline Chhindwara & $28.1-85.3$ & $9.1-15.6$ & $37.1-100.9$ & Pande (2005) \\
\hline Madhya Pradesh (Dry Deciduous) & 54.9 & - & - & Salunkhe et al. (2016) \\
\hline Madhya Pradesh (Mixed Deciduous) & 44.5 & - & - & Salunkhe et al. (2016) \\
\hline
\end{tabular}

Himalaya region of India, showing an increase from $0.5 \mathrm{Mg} \mathrm{ha}{ }^{-1}$ at 1 year to $90.1 \mathrm{mg} \mathrm{ha}^{-1}$ at 11 years. The total carbon stock (AGB and soil) increased from $64.4 \mathrm{mg} \mathrm{ha}^{-1}$ at 1 year to $173.9 \mathrm{mg} \mathrm{ha}^{-1}$ at 11 years. They concluded that Populus deltoides as a viable option for sustainable production and carbon mitigation. In the agroforestry land use system of Kwalkhad water-shed of middle Himalayan region of Himachal Pradesh, India, Goswami et al. (2014) evaluated carbon sequestration and $\mathrm{C}$ credits as $14.78 \mathrm{mg} \mathrm{ha}^{-1}$ in agrisilvihorticulture and $14.45 \quad \mathrm{Mg} \quad \mathrm{ha}^{1}$ in agrihortisilviculture systems.

Kumar and Sharma (2015) estimated forest carbon (C) stock of Balganga Reserved Forest (BRF) in district Tehri Garhwal, Uttarakhand, India. Results showed highest total biomass density (TBD) and total carbon density (TCD) estimates at site III in the altitudinal range of $1800-2600 \mathrm{~m}$ as 108.26 and $53.45 \mathrm{Mg} \mathrm{ha}^{-1}$ followed by site II in the range of $1600-1800 \mathrm{~m}$ as 83.92 and $41.96 \mathrm{Mg} \mathrm{ha}{ }^{-1}$, and lowest at site I in the altitudinal

Table 6 Standing biomass of different forest types of India

\begin{tabular}{llll}
\hline Sr. No. & Forest Types & Standing biomass $\left(\mathrm{t} \mathrm{ha}^{-1}\right)$ & Reference \\
\hline 1 & Tropical wet evergreen & 607.7 & Rai (1981) \\
2 & Tropical semi evergreen & 468.0 & Swami (1989) \\
3 & Tropical moist deciduous & 409.3 & Swami (1989) \\
4 & Littoral and swamp & 213.8 & Singh (1989) \\
5 & Tropical dry deciduous & 93.8 & (1990) \\
6 & Tropical thorn ${ }^{\text {a }}$ & 40.0 & Toky and Ramakrishnan (1982) \\
7 & Tropical dry evergreen & Chaturvedi and Singh (1984) \\
8 & Subtropical broad leafed hill & 40.0 & Yadava (1986) \\
9 & Subtropical Pine & 108.7 & Rana (1985) \\
10 & Subtropical dry evergreen &
\end{tabular}

Source: Ravindranath et al. (1997)

${ }^{a}$ Tropical thorn forest were assumed to have $40 \%$ of the crown cover of tropical dry deciduous forests as they appear alongside the tropical dry deciduous forest; $40 \%$ of standing biomass of deciduous forests were assumed to be the standing biomass of tropical thorn forests, which is $37.52 \mathrm{t}^{-1} \mathrm{further}^{-10 u n d e d}$ off to $40 \mathrm{t} \mathrm{ha}^{-1}$

${ }^{\mathrm{b}}$ Same as tropical thorn forest

"Since it occurs between subtropical pine and tropical dry deciduous forests, a mid value between the standing biomass values of these two forests types is used

${ }^{d}$ Since it occurs between subtropical pine and subalpine forests, a mid value between the standing biomass values of these two forests types is used 
range of $1000-1400 \mathrm{~m}$ as 57.22 and $28.61 \mathrm{Mg} \mathrm{ha}^{-1}$ with an average of 83.13 and $41.56 \mathrm{Mg} \mathrm{ha}^{-1}$, respectively. According to Mandal and Joshi (2015), invasive shrubs also play an important role in atmospheric carbon assimilation. They calculated highest biomass $\left(13,559.60 \mathrm{~kg} \mathrm{ha}^{-1}\right)$ and carbon density $\left(6373.01 \mathrm{~kg} \mathrm{ha}^{-1}\right)$ of Lantana camara L. with the help of allometric equation at Doon valley, Western Himalaya. In the Cypress forest of central Himalaya, Rana et al. (2015) reported that total biomass of trees across all the sites ranged between 178 and $431 \mathrm{t} \mathrm{ha}^{-1}$, while carbon stock ranged between 89.07 and $206 \mathrm{t} \mathrm{ha}^{-1}$.

Singh et al. (2016) estimated carbon sequestration potential of tropical dry deciduous forests in three protected forests of Gurgaon district, southern Haryana. They found the AGB of trees in the three forests as 37.93 to 63 . $73 \mathrm{Mg} \mathrm{ha}^{-1}$ and below ground biomass as 11.12 to $17.81 \mathrm{Mg} \mathrm{ha}{ }^{-1}$. The total carbon pools in the three forests were $52.59 \mathrm{Mg} \mathrm{ha}^{-1}$ at Ailanthus excelsaCassia fistula forest, followed by $34.17 \mathrm{Mg} \mathrm{ha}^{-1}$ for Acacia leucophloea-Balanites aegyptica forest, and $33.61 \mathrm{Mg} \mathrm{ha}{ }^{-1}$ in Anogeissus pendula-Acacia leucophloea dominated forest. Majumdar et al. (2016) estimated biomass of selected tropical forest patches of Tripura, Northeast India, using allometric equations. The biomass ranged in between 37.85 to $85.58 \mathrm{Mg} \mathrm{ha}^{-1}$. Studies from community-managed forest at Garhwal Himalaya, India, showed total biomass and carbon density as $132.74 \mathrm{Mg} \mathrm{ha}{ }^{-1}$ and $66.36 \mathrm{Mg} \mathrm{ha}{ }^{-1}$, respectively (Mahato et al. 2016). Very high aboveground biomass density $\left(78.20 \pm 17.41 \mathrm{t} \mathrm{ha}^{-1}\right)$ was found in Quercus leucotrichophora followed by Pinus roxburghii. In tea agroforestry system of Barak valley, Assam, North East India, Kalita et al. (2016) estimated carbon stock using species specific volume equations, wood-specific gravity, and biomass expansion factor. The results showed that carbon stock in 6,14 , and 22 years old plantation were $44.8 \pm 1.3,50.2 \pm 4.6$, and $56.7 \pm 4.9 \mathrm{Mg} \mathrm{C}$ $\mathrm{ha}^{-1}$, respectively.

Thokchom and Yadava (2017) estimated biomass and carbon stock along an altitudinal gradient in the forest of Manipur, Northeast India. The aboveground biomass ranged between 124.56 and $254.99 \mathrm{t} \mathrm{ha}^{-1}$ and carbon stock ranged from 60.09 to $121.43 \mathrm{t} \mathrm{ha}^{-1}$ across the study area. At Poplar (Populus deltoides) agroforestry system in Yamunanagar and Saharanpur districts of Northwestern India, biomass production and carbon stock were estimated by Rizvi et al. (2011). The contribution of Poplar plantation to carbon storage was found $27-32 \mathrm{t} \mathrm{ha}^{-1}$ in boundary system, whereas it was $66-83 \mathrm{t} \mathrm{ha}^{-1}$ in agrisilviculture system at rotation period of 7 years in the two districts. They also concluded that Poplar plantations may play a significant role in atmospheric $\mathrm{CO}_{2}$ assimilation. In the Eastern Himalayas,
North-East India, Gogoi et al. (2017) estimated carbon stock of rain forest using suitable regression equations, and they found highest stock $\left(306.61 \pm 17.14 \mathrm{Mg} \mathrm{C} \mathrm{ha}^{-1}\right)$ in least disturbed site. Moderately distributed and highly distributed site showed $169.91 \pm 2.59 \mathrm{Mg} \mathrm{C}^{-1}$ and 102 . $43 \pm 3.18 \mathrm{Mg} \mathrm{C} \mathrm{ha}^{-1}$, respectively. They also attributed that carbon sequestration is impacted by anthropogenic disturbances in forest ecosystems. Niirou and Gupta (2017) reported tree carbon stock ranging from $25.59 \mathrm{t} \mathrm{ha}^{-1}$ to $164.81 \mathrm{t} \mathrm{ha}^{-1}$ and basal area from $10.13 \mathrm{~m}^{2} \mathrm{ha}^{-1}$ to 92 . $04 \mathrm{~m}^{2} \mathrm{ha}^{-1}$, in Oak- and Pine-dominant forests using regression equation models at Senapati district of Manipur, India.

\section{Central Indian forest ecosystem biomass/carbon estimation}

Kale et al. (2004) developed allometric equations for estimation of bole biomass of five prominent species from dry deciduous forest in Shivpuri district, Madhya Pradesh, Central India, using nondestructive method. For estimation of AGB, Bijalwan et al. (2010b) used nondestructive approach based on DBH, height, and volume equations. They reported 78,170.72 Mg, 81,656.91 Mg, and $7470.45 \mathrm{Mg} \mathrm{C}$ in mixed, degraded, and Sal mixed forests, respectively, in dry tropical forests of entire area of Chhattisgarh region of Central India using satellite remote sensing and GIS. Bijalwan et al. (2010a) estimated biomass and carbon in dry tropical forest of Chhattisgarh region in India with the help of satellite remote sensing and GIS technology. The results of standing volume, AGB, and C storage varied from 35.59 to $64.31 \mathrm{~m}^{2} \mathrm{ha}^{-1}$, 45.94 to $78.31 \mathrm{Mg} \mathrm{ha}{ }^{-1}$, and 22.97 to $33.27 \mathrm{Mg} \mathrm{ha}^{-1}$, respectively. With the help of DLR-ESAR multi-frequency data, Nizalapur et al. (2010) estimated the AGB of Indian tropical forests in Gujarat, India. They reported that Cband ESAR data predict $70 \mathrm{Mg} \mathrm{ha}{ }^{-1}$, L-band up to $150 \mathrm{Mg} \mathrm{ha}^{-1}$, and P-band up to $200 \mathrm{Mg} \mathrm{ha}^{-1}$. Phytomass of moist deciduous forest of Gujarat, India, estimated with the help of spectral modeling showed a range from 6 . $13 \mathrm{t} \mathrm{ha}^{-1}$ to $389.166 \mathrm{t} \mathrm{ha}^{-1}$, while it was $5.534-134$. $082 \mathrm{t} \mathrm{ha}^{-1}$ using area weights for $250 \times 250 \mathrm{~m}$ sites. The mean biomass of study area was reported as $40.50 \mathrm{t} \mathrm{ha}^{-1}$ with mean C density of 19.44 $\mathrm{t} \mathrm{C} \mathrm{ha}^{-1}$ (Patil et al. 2012). Chaturvedi et al. (2012) addressed the effects of grazing, harvesting, and carbon accumulation of juvenile trees at five sites of tropical dry forest of Uttar Pradesh, India. The results indicate that the carbon density in the juvenile tree population ranged from 271 to $966 \mathrm{~kg}-\mathrm{C} \mathrm{ha}{ }^{-1}$ and carbon accumulation from 10 to $2010 \mathrm{~g}-\mathrm{C} \mathrm{cm}^{-2} \mathrm{yr}^{-1}$.

Kumar et al. (2011) estimated mean AGB from northern Haryana, the range being from $30.46 \mathrm{Mg} \mathrm{ha}^{-1}$ to $310.10 \mathrm{Mg} \mathrm{ha}{ }^{-1}$ across all forest types. While the total AGB and C stocks were $26.99 \mathrm{Tg}$ and $12.96 \mathrm{Tg}$. According to Kumar et al. (2011), the biomass of trees 
varies with age from $183.7 \pm 3.21$ to $298.3 \pm 3.57 \mathrm{t} \mathrm{ha}^{-1}$ in Butea monosperma forest ecosystem in Western India, Rajasthan. Pandya et al. (2013) estimated carbon storage in 25 species from Gujarat state of India, using nondestructive allometric equation approach. They reported that trees store 177.5 million tonnes of carbon out of which the selected 25 tree species contributed (the sum of all species carbon) $421.47 \times 10^{-6}$ million tones carbon. The lowest carbon storage value estimated in Emblica officinalis $1.77 \mathrm{tC}$ and maximum carbon storage found in Tamarindus indica 55.95tC. Studies on fast-growing tree plantation under agroforestry system adopting strategies for sustainable tree-crop production and $C$ sequestration improvement in subhumidtropics of Chhattisgarh, India, were done by Swami and Mishra (2014). They reported that total biomass varied from $12.9 \mathrm{Mg} \mathrm{ha}^{-1}$ to $25.1 \mathrm{Mg} \mathrm{ha}^{-1}$ in 5-year-old Ceiba pentandra trees, in Gmelina arborea $9.9 \mathrm{Mg} \mathrm{ha}^{-1}$ to 21.4 $\mathrm{Mg} \mathrm{ha}{ }^{-1}$, and in Populus deltoides clones, total biomass ranged from $48.5 \mathrm{Mg} \mathrm{ha}^{-1}$ to $62.2 \mathrm{Mg} \mathrm{ha}^{-1}$.

Salunkhe et al. (2014) estimated AGB and C stock in tropical deciduous forests of state of Madhya Pradesh, India. The AGB ranged from 3.99 to $53.90 \mathrm{t} \mathrm{ha}^{-1}$ and carbon stock ranged from 1.89 to $25.6 \mathrm{t} \mathrm{ha}^{-1}$ across different study sites. According to Chaturvedi and Raghubanshi (2015), the average aboveground carbon density and carbon accumulation of mono and multispecific Tectona grandis and Shorea raobusta forests in tropical dry region of India were $136 \mathrm{t} \mathrm{cha}^{-1}$ and $5.3 \mathrm{t}$ $\mathrm{cha}^{-1} \mathrm{yr}^{-1}$, respectively. Lal et al. (2016) estimated carbon storage pattern in natural and plantation forests of subhumid tropics in Barnawapara Wildlife Sanctuary, Chhatisgarh, India, using allometric equations. The maximum total (above and below) carbon was found in closed natural forest (208.22 $\mathrm{Mg} \mathrm{ha}^{-1}$ ) followed by open natural forests (95.11 $\mathrm{Mg} \mathrm{ha}^{-1}$ ) and Teak plantation (56. $06 \mathrm{mg} \mathrm{ha}^{-1}$ ). They also concluded that in terms of carbon storage, natural forest has an edge over the plantation forest. In studies on tropical deciduous forest ecosystems of Madhya Pradesh, India, Salunkhe and Khare (2016) estimated carbon stock in four different types of forests, viz., mixed non-Teak forest (MNTF) as 25-54 $\mathrm{Mg} \mathrm{ha}^{-1}$, dry mixed non-Teak forest (DMNTF) as $13-42 \mathrm{Mg} \mathrm{ha}^{-1}$, Teak-dominated forest (TDF) as 33-53 $\mathrm{Mg} \mathrm{ha}^{-1}$, and dry Teak forest (DTF) as 16-24 Mg ha ${ }^{-1}$. Biomass and carbon stocks of different tree plantations of eastern Chhatisgarh, India, were highest $\left(942.50 \mathrm{t} \mathrm{ha}^{-1}\right)$ in Albizia lebbeck followed by Eucalyptus globules (520.62 t ha ${ }^{-1}$ ), Terminalia arjuna (143.12 $\left.\mathrm{t} \mathrm{ha} \mathrm{ha}^{-1}\right)$, and Azadirachta indica (106.87 $\mathrm{t} \mathrm{ha}^{-1}$ ) (Bhardwaj and Chandra 2016).

South Indian forest ecosystem biomass/carbon estimation Mani and Parthasarathy (2007) estimated AGB in inland and costal tropical dry evergreen forests of Peninsular
India. Using basal area method, they reported that AGB ranged from 39.69 to $170.02 \mathrm{Mg} \mathrm{ha}^{-1}$, whereas estimates based on basal area and height method, it was 73.06$173.10 \mathrm{Mg} \mathrm{ha}^{-1}$. In both the forests types, basal area (BA) and AGB showed positive relationship. Kale et al. (2009) estimated carbon sequestration and concluded that natural plantation had highest rate $\left(20.27 \mathrm{t} \mathrm{ha}^{-1}\right)$ of carbon sequestration than mixed moist deciduous natural forest in Western Ghats. Bhat and Ravindranath (2011) work out incremental aboveground standing biomass in tropical rain forest of Uttara kannada district of Western Ghat using specific equation approach, which ranged from 6.40 to $144.67 \mathrm{t} \mathrm{ha}^{-1}$. The biomass productivity and carbon stocks of farm forestry and agroforesty systems of Leucaena and Eucalyptus in Andhra Pradesh were analyzed by Prasad et al. (2012). The carbon stocks of Leucaena and Eucalyptus are $62 \mathrm{Mg} \mathrm{ha}^{-1}$ and $34 \mathrm{Mg} \mathrm{ha}^{-1}$, respectively. They also concluded that Leucaena and Eucalyptus system can play an important role as carbon sinks.

Sundarapandian et al. (2013) estimated biomass in five study sites-four plantations and a natural forest at Puthupet, Tamil Nadu. The AGB for Anacardium occidentale, Casuarina equisetifolia, Mangifera indica, Coccus nucifera, and natural forest were 32.7, 38.1, 121.1, 143.2, and $227.2 \mathrm{Mg} \mathrm{ha}^{-1}$, respectively. Maximum carbon stock was reported from natural forest site $\left(131.8 \mathrm{Mg} \mathrm{ha}^{-1}\right)$. Study suggested that for reducing atmospheric $\mathrm{CO}_{2}$ concentration, managed plantations are helpful. The aboveground biomass and carbon stock of Mysore district (19 and $9 \mathrm{t} \mathrm{ha}^{-1}$, respectively) and Hassan district (24 and $12 \mathrm{t} \mathrm{ha}^{-1}$, respectively) were reported by Devagiri et al. (2013) for dry deciduous forest of western part of Karnataka, India, using allometric volume equations.

Pragasan (2014) determined AGB of tree species in the Pachaimalai forest of the Eastern Ghats in India. Results showed that the average biomass value was $25.3 \pm 5$. $6 \mathrm{t} \mathrm{ha}^{-1}$ with a range from 4.2 to $103.5 \mathrm{t} \mathrm{ha}^{-1}$ with the total stock 12 ha as 608.5 t. According to Sundarapandian et al. (2014), total carbon stock of Pondicherry University campus forest was $14.9 \mathrm{Mg} \mathrm{ha}^{-1}$. Rao and Rao (2015) studied the total standing biomass and carbon stocks of tropical deciduous forest of Nallamalais, India. Results revealed that biomass and carbon stock of study area were $56.47 \mathrm{Mt}$. and 26.34 Mt., respectively. In tropical forests of Bodamalai hills, Tamil Nadu, Pragasan (2015) recorded total carbon stock as 10. $9 \pm 3.6 \mathrm{tC} \mathrm{ha}^{-1}$ with tree carbon stock from $3.53 \mathrm{tC} \mathrm{ha}^{-1}$ to $38.92 \mathrm{tC} \mathrm{ha}^{-1}$. Vivek and Parthasarathy (2015) reported trees and lianas carbon stock from tropical dry evergreen forests of Coromandel Coast of India. The total trees AGB were $3025.8 \mathrm{Mg} \mathrm{ha}^{-1}$ across ten sites. The AGB of lianas ranged from $2.24 \mathrm{Mg} \mathrm{ha}^{-1}$ to $42.13 \mathrm{Mg} \mathrm{ha}^{-1}$ with total contribution of $153.76 \mathrm{Mg} \mathrm{ha}{ }^{-1}$. Subashree and 
Sundrapandian (2017) carried out carbon inventories for savannah ecosystems of Kanyakumari Wildlife Sanctuary, Western Ghats, India. Results showed that the total vegetation carbon accounted was $216.2 \mathrm{Mg} \mathrm{C} \mathrm{ha}{ }^{-1}$ and 206.6 $\mathrm{Mg} \mathrm{C} \mathrm{ha}{ }^{-1}$ at two different sites.

\section{Conclusion}

Forests are the principal natural carbon pool and act as carbon source and sink. Tropical forests are potentially capable to mitigate climate change and global warming by sequestering carbon from atmosphere. Understanding of global carbon cycle is a difficult and complex task due to changing land use, degradation of existing forests, and other anthropogenic influences. Further, accurate data on carbon sequestration and stocks are highly deficient especially from tropical forests of India where diverse forest communities exist due to highly variable climatic and geographical conditions.

In the present paper, we tried to explore and comprehend scientific studies conducted in Indian forests related to aboveground biomass and carbon stock from almost all forest types including plantations and agroforestry systems. The methods involved for estimation of biomass and carbon stock are classified as destructive and nondestructive approaches. While the former is now not practically considered due to conservational point of view except in small uniform forest communities, the latter depends on measurable parameters such as girth at breast height, tree height, volume, and wood density. Estimation are also carried out based on remote sensing data; however, it also requires validation from field.

Tropical wet evergreen forest types appear to stock more biomass. However, tropical deciduous forests contribute more to the total biomass and carbon stock on account of their area. Studies indicate that for estimation, usually general volume equations are used that have been developed by forest institutes and other workers. Species-specific equations are also available; however, they may not give sufficiently good estimation due to forest degradation variations and habitat variability. Therefore, there is a need to develop specific equations from different habitats and conditions of degradation in forests.

Present paper summarized various estimates from different forest types in India, related to biomass and carbon stock, pool, and sequestration. The estimates can be utilized for generating a data base that could be useful for policy-making particularly related to mitigation of climate change and conservation.

\section{Abbreviations}

AGB: Aboveground biomass; BA: Basal area; C: Carbon; REDD+: Reducing emission from deforestation and forest degradation

\section{Acknowledgements}

Authors are thankful for contributors of all the research papers and information cited in the paper. Authors are also grateful to reviewers for comments and improvements suggested.

Funding

There was no funding receive from any funding source for this publication.

Availability of data and materials

Publically available

Authors' contributions

OS and PK designed and drafted the manuscript. RK contributed to the arranging the data and MLK contribute to revision of first draft. All authors have read and approved the final manuscript.

Ethics approval and consent to participate

Not applicable

\section{Competing interests}

The authors declare that they have no financial and nonfinancial competing interests.

\section{Publisher's Note}

Springer Nature remains neutral with regard to jurisdictional claims in published maps and institutional affiliations.

Received: 9 November 2017 Accepted: 19 April 2018

Published online: 14 May 2018

\section{References}

Anaya JA, Chuvieco E, Palacios-Orueta A (2009) Aboveground biomass assessment in Colombia: a remote sensing approach. For Ecol Manag 257: 1237-1246.

Arora G, Chaturvedi S, Kaushal R, Nain A, Tewari S, Alam NM, Chaturvedi OP (2014) Growth, biomass, carbon stocks, and sequestration in an age series of Populus deltoids plantations in Tarai region of central Himalaya. Turk J Agric For 38:550-560.

Baccini A, Friedl MA, Woodcock CE, Warbington R (2004) Forest biomass estimation over regional scales using multisource data. Geophys Res Lett 31:1-4

Baishya R, Barik SK (2011) Estimation of tree biomass, carbon pool and net primary production of an old-growth Pinus kesiya Royle ex. Gordon forest in North-Eastern India. Ann For Sci 68:727-736.

Bandhu D (1970) A study of productive structure of northern tropical dry deciduous forest near Varanasi. I. Stand structure and non-photo-synthetic biomass. Trop Ecol 11:90-104.

Basuki TM, Van Laake PE, Skidmore AK, Hussin YA (2009) Allometric equations for estimating the above-ground biomass in tropical lowland dipterocarp forests. For Ecol Manag 257:1684-1694.

Beer C, Reichstein M, Tomelleri E, Ciais $P$, Jung $M$, Carvalhais $N$, Roedenbeck C, Arain MA, Baldocchi D, Bonan GB et al (2010) Terrestrial gross carbon dioxide uptake: global distribution and covariation with climate. Science 329:834-838.

Bhardwaj AK, Chandra KK (2016) Biomass and carbon stocks of different tree plantations in entisol soil of Eastern Chhattisgarh India. Curr World Environ 11(3):819-824.

Bhat DM, Ravindranath NH (2011) Above-ground standing biomass and carbon stock dynamics under a varied degree of anthropogenic pressure in tropical rain forests of Uttara Kannada District, Western Ghats, India. Taiwania 56(2): 85-96.

Bijalwan A (2010a) Structure, composition and diversity of degraded dry tropical forest in Balamdi Watershed of Chhattisgarh Plain, India. J Biodivers 1(2):119-124

Bijalwan A, Swamy SL, Sharma CM, Sharma NK, Tiwari AK (2010b) Land-use, biomass and carbon estimation in dry tropical forest of Chhattisgarh region in India using satellite remote sensing and GIS. J For Res 21(2):161-170.

Borah N, Nath AJ, Das AK (2013) Aboveground biomass and carbon stocks of tree species in tropical forests of Cachar District, Assam, Northeast India. Int J Ecol Environ Sci 39(2):97-106. 
Brown S, Gillespie A, Lugo A (1989) Biomass estimation methods for tropical forests with applications to forest inventory data. For Sci 35:881-902.

Brown SL, Schroeder P, Kern JS (1999) Spatial distribution of biomass in forests of the Eastern USA. For Ecol Manag 123:81-90.

Butler RA (2016) The top 10 most biodivers countries. Mongabay. Available at https://news.mongabay.com/2016/05/top-10-biodiverse-countries/.

Cannell MGR (1982) World forest biomass and primary productivity data. Academic Press, Landon.

Champion HG, Seth SK (1968) A revised survey of the forest types of India. Government of India Publications, Delhi, India.

Chaturvedi OP, Singh JS (1984) Potential biomass energy from all-aged Chir Pine forest of Kumaun Himalaya. Biomass 5(2):161-65.

Chaturvedi RK, Raghubanshi AS (2015) Assessment of carbon density and accumulation in mono- and multi-specific stands in Teak and Sal forests of a tropical dry region in India. For Ecol Manag 339:11-21.

Chaturvedi RK, Raghubanshi AS, Singh JS (2012) Effect of grazing and harvesting on diversity, recruitment and carbon accumulation of juvenile trees in tropical dry forests. For Ecol Manag 284:152-162.

Chhabra A, Palria S, Dadhwal VK (2002a) Growing stock-based forest biomass estimate for India. Biomass Bioenergy 22:187-194.

Chhabra A, Parila S, Dadhwal VK (2002b) Spatial distribution of phytomass and carbon in Indian forest. Glob Chang Biol 8:1230-1239.

Chung-Wang X, Ceulemans R (2004) Allometric relationships for below and aboveground biomass of young Scots pines. For Ecol Manag 203:177-186.

Clark DB, Clark DA (2000) Landscape scale variation in forest structure and biomass in a tropical rain forest. For Ecol Manag 137:185-198.

Dadhwal VK, Nayak SR (1993) A preliminary estimate of biogeochemical cycle of carbon for India. Sci Cult 59(12):9-13.

Dadhwal VK, Shah A (1997) Recent changes in forest phytomass carbon pool in India estimated using growing stock and remote sensing based forest inventories. J Trop Forestry 13:182-188.

Dadhwal VK, Pandya N, Vora AB (1998) Carbon cycle for Indian forest ecosystem: a preliminary estimate. In: Subbaraya BH, Rao DP, Desai PS, Manikiam RP (eds) Global change studies: scientific results from ISRO-GBP. ISRO, Bangalore, pp 411-430.

Day SK (2005) A preliminary estimation of carbon stock sequestrated through rubber (Havea brasiliensis) plantation in north-eastern region of India. Indian Forester 131(11):1429-1436.

de Gier A (2003) A new approach to woody biomass assessment in wood lands and shrub lands. In: Roy P (ed) Geoinformatics for tropical ecosystems. IBD, Mumbai, pp 161-198.

Devagiri GM, Money S, Singh S, Dadhwal VK, Patil P, Khaple A, Devkumar AS, Hubballi S (2013) Assessment of aboveground biomass and carbon pool in different vegetation types of south western part of Karnataka, India using spectral modeling. Trop Ecol 54:149-165.

Devi SL, Yadava PS (2009) Aboveground biomass and net primary production of semievergreen tropical forest of Manipur, North Eastern India. J For Res 20(2):151-155.

Drake JB, Knox RG, Dubayah RO, Clark DB, Condit R et al (2003) Aboveground biomass estimation in closed canopy Neotropical forest using lidar remote sensing: factors affecting the generality of relationships. Global Ecol Biogeogr 12:147-159.

FSI: State of Forest Report (1999) Forest Survey of India, Ministry of Environment and Forest, Government of India.

FSI (2011) State of forest report 2011. Forest Survey of India, FSI (Ministry of Environment and Forests) Government of India, Dehradun.

Gairola S, Sharma CM, Ghildiyal SK, Suyal S (2011) Live tree biomass and carbon variation along an altitudinal gradient in moist temperate valley slopes of the Garhwal Himalaya (India). Curr Sci 100(12):1862-1870.

George M, Varghees G, Manivachakam P (1990) Nutrient cycling in Indian tropical dry deciduous forest ecosystem. In: Proceeding of the seminar on forest productivity held at F.R.I. Dehradun, 23-24 Apr 1990, pp 289-297.

Gibbs HK, Brown S, Niles JO, Foley JA (2007) Monitoring and estimating tropical forest carbon stocks: making REDD a reality. Environ Res Lett 2:1-13.

Giri N, Rawat L, Kumar P (2014) Assessment of biomass carbon stock in a Tectona grandis Linn F. Plantation ecosystem of Uttarakhand, India. Int J Eng Sci Inven 3(5):46-53.

Gogoi A, Sahoo UK, Singh SL (2017) Assessment of biomass and total carbon stock in a tropical wet evergreen rainforest of Eastern Himalaya along a disturbance gradient. J Plant Bio Soil Health 4(1):1-8.

Goswami S, Verma KS, Kaushal R (2014) Biomass and carbon sequestration in different agroforestry systems of a Western Himalayan watershed. Bio Agric Horti 30(2):88-96.
Han FX, Plodinec MJ, Su Y, Monts DL, Li Z (2007) Terrestrial carbon pools in southeast and South-Central United States. Clim Chang 84:191-202.

Haripriya GS (2003) Carbon budget of the Indian forest ecosystem. Clim Chang 56:291-319.

Hashimotio T, Kojima K, Tange T, Satohiko S (2000) Changes in carbon storage in fallow forests in the tropical lowlands of Borneo. For Ecol Manag 126:331-337.

Hingane LS (1991) Some aspects of carbon dioxide exchange between atmosphere and Indian plant biota. Clim Chang 18:425-435.

Hughes RF, Kauffman JB, Jaramillo VJ (1999) Biomass, carbon, and nutrient dynamics of secondary forests in a humid tropical region of Mexico. Ecology 80:1897-1907.

IPCC (2007) Hegerl, G.C., F. W. Zwiers, P. Braconnot, N.P. Gillett, Y. Luo, J.A Marengo Orsini, N. Nicholls, J.E. Penner and P.A. Stott, 2007: understanding and attributing climate change. In: Solomon S, Qin D, Manning M, Chen Z, Marquis M, Averyt KB, Tignor M, Miller HL (eds) Climate Change 2007: the physical science basis. Contribution of working group I to the fourth assessment report of the Intergovernmental Panel on Climate Change. Cambridge University Press, Cambridge, UK/New York.

Kale M, Singh S, Roy PS, Deosthali V, Ghole VS (2004) Biomass equations of dominant species of dry deciduous forest in Shivpuri district, Madhya Pradesh. Curr Sci 87(5):683-687.

Kale MP, Ravan SA, Roy PS, Singh S (2009) Patterns of carbon sequestration in forests of Western Ghats and study of applicability of remote sensing in generating carbon credits through afforestation/reforestation. J Indian Soc Rem Sens 37:457-471.

Kalita RM, Das AK, Nath AJ (2016) Carbon stock and sequestration potential in biomass of tea agroforestry system in Barak Valley, Assam, North East India. Int J Ecol Environ Sci 42(S):107-114.

Kaul ON, Sharma DC, Tandon VN, Srivatava PBL (1979) Organic matter and plant nutrients in a teak (Tectona grandis) plantation. Indian Forester 105:573-582.

Kaul MG, Mohren MJ, Dadhwal VK (2011) Phytomass carbon pool of trees and forests in India. Clim Chang 108:243 259.

Kishwan J, Pandey R, Dadhwal VK (2009) India's forest and tree cover: contribution as a carbon sink. Indian Council of Forestry Research and Education, Dehradun.

Kumar A, Sharma MP (2015) Estimation of carbon stocks of Balganga Reserved Forest, Uttarakhand, India. For Sci Technol 11(4):177-181.

Kumar NJI, Patel K, Kumar RN, Kumar BR (2011) Forest structure, diversity and soil properties in a dry tropical forest in Rajasthan, Western India. Ann For Res 54(1):89-98.

Kumar R, Gupta SR, Singh S, Patil P, Dhadhwal VK (2011) Spatial distribution of forest biomass using remote sensing and regression models in Northern Haryana, India. Int J Ecol Environ Sci 37(1):37-47.

Lal M, Singh R (2000) Carbon sequestration potential of Indian forests. Environ Monit Asst 60:315-327.

Lal C, Singh L, Sarvade S, Atri V (2016) Biomass and carbon storage pattern in natural and plantation forests of sub-humid tropics in Barnawapara Wildlife Sanctuary, Chhattisgarh, India. Int J Ecol Environ Sci 42:83-90.

Lodhiyal N, Lodhiyal LS (2003) Biomass and net primary productivity of Bhabar Shisham forests in Central Himalaya, India. For Ecol Manag 176:217-235.

Lu D (2006) The potential and challenge of remote sensing-based biomass estimation. Int J Rem Sens 27:1297-1328.

Mahato S, Dasgupta S, Todaria NP (2016) Tree and soil carbon stock by community managed forests in Garhwal Himalaya. Plant Arch 16(2):805-811.

Majumdar K, Choudhary BK, Datta BK (2016) Aboveground woody biomass, carbon stocks potential in selected tropical forest patches of Tripura, Northeast India. Open J Ecol 6:598-612.

Mandal G, Joshi SP (2015) Estimation of above-ground biomass and carbon stock of an invasive woody shrub in the subtropical deciduous forests of Doon Valley, Western Himalaya, India. J For Res 26(2):291-305.

Manhas RK, Negi JDS, Kumar R, Chauhan PS (2006) Temporal assessment of growing stock, biomass and carbon stock of Indian forests. Clim Chang 74:191-221.

Mani S, Parthasarathy N (2007) Above-ground biomass estimation in ten tropical dry evergreen forest sites of peninsular India. Biomass Bioenergy 31:284-290.

MEA: Millennium Ecosystem assessment (2005) Ecosystems and Human well being: Synthesis. Island Press, Washington, DC.

Montès N, Gauquelin T, Badri W, Bertaudiere V, Zaoui EH (2000) A nondestructive method for estimating above-ground forest biomass in threatened woodlands. For Ecol Manag 130:37-46. 
Murali KS, Bhat DM, Ravindranath NH (2005) Biomass estimation equations for tropical and evergreen forests. Int J Agric Resour Govrn Ecol 4:81-92.

Murthy IK, Kumar AA, Ravindranath NH (2012) Potential for increasing carbon sink in Himachal Pradesh, India. Trop Ecol 53(3):357-369.

Nautiyal N, Singh V (2013) Carbon stock potential of oak and pine forests in Garhwal region in Indian Central Himalayas. J Pharm Phytochem 2(1):43-48.

Navár J (2009) Allometric equations for tree species and carbon stocks for forests of Northwestern Mexico. For Ecol Manag 257:427-434.

NEFA (2002) North East State Forest Association. Carbon sequestration and its impacts on forest management in the northeast. Available at http://www. nefainfo.org/publications/carbonsequestration.pdf.

Negi JDS, Bahuguna VK, Sharma DC (1990) Biomass production and distribution of nutrients in 20 years old teak (Tectona grandis) and gamar (Gmelina arborea) plantation in Tripura. Indian Forester 116:681-686.

Negi MS, Tandon VN, Rawat HS (1995) Biomass and nutrient distribution in young teak (Tectona grandis Linn f) plantations in Tarai region of Uttar Pradesh. Indian For 121:455-464.

Nelson BW, Mesquita R, Pereira JLG, Aquino de Sauza SG, Batista GT et al (1999) Allometric regressions for improved estimate of secondary forest biomass in the Central Amazon. For Ecol Manag 117:149-167.

Niirou N, Gupta A (2017) Phytosociological analysis and carbon stocks for trees in different land uses in Senapati district of Manipur, India. Pleione 11(1):64-70.

Nizalapur V, Jha CS, Madugundu R (2010) Estimation of aboveground biomass in Indian tropical forested area using multi-frequency DLR-ESAR data. Int J Geo Geosci 1(2):167-178.

Nowak DJ (1993) Atmospheric carbon reduction by urban trees. J Environ Manag 37:207-217.

Pala NA, Negi AK, Gokhale Y, Aziem S, Vikrant KK, Todaria NP (2013) Carbon stock estimation for tree species of Sem Mukhem sacred forest in Garhwal Himalaya, India. J For Res 24(3):457-460.

Pande PK (2005) Biomass and productivity in some disturbed tropical dry deciduous teak forest of Satpura plateau, Madhya Pradesh. Trop Ecol 46:229-239.

Pandya IY, Salvi H, Chahar O, Vaghela N (2013) Quantitative analysis on carbon storage of 25 valuable tree species of Gujarat, Incredible India. Indian J Sci Res 4(1):137-141.

Patil P, Singh S, Dadhwal VK (2012) Aboveground forest phytomass assessment in Southern Gujarat. J Indian Soc Rem Sens 40(1):37-46.

Pragasan AL (2014) Assessment of aboveground biomass stock in the Pachaimalai forest of Eastern Ghats in India. Appl Ecol Environ Res 13(1):133-145.

Pragasan AL (2015) Tree carbon stock assessment from the tropical forests of Bodamalai Hills located in India. Earth Sci Clim Change 6:10.

Prasad JVNS, Srinivas K, Rao CS, Ramesh C, Venkatravamma K, Venkateswarlu B (2012) Biomass productivity and carbon stocks of farm forestry and agroforestry systems of leucaena and eucalyptus in Andhra Pradesh, India. Curr Sci 103(5):536-540.

Rai SN (1981) Productivity of tropical rain forests of Karnataka. PhD thesis, University of Bombay, Bombay, India.

Raizada A, Parandiyal AK, Ghosh BN (2003) Estimation of carbon flux through litter fall in forest plantation of India. Indian Forester 129(7):881-894.

Rana BS (1985) Biomasss and net primary productivity in different forest ecosystems along an altitudinal gradients in Kumaun Himalaya. PhD thesis, Kumaun University, Naini Tal, India.

Rana S, Bargali K, Bargali SS (2015) Assessment of plant diversity, regeneration status, biomass and carbon stock in a Central Himalayan cypress forest. Int J Biodivers Conserv 7(6):321-329.

Ranawat MPS, Vyas LN (1975) Litter production in deciduous forests of Koriyat, Udaipur (South Rajasthan), India. Biologia 30:41-47.

Rao VS, Rao BRP (2015) Carbon sequestration potential of tropical deciduous forests of Nallamalais, India. Asian J Plant Sci Res 3:24-33.

Ravindranath NH, Ostwald M (2008) Methods for estimating above-ground biomass. In: Ravindranath NH, Ostwald M (eds) Carbon inventory methods: handbook for greenhouse gas inventory, carbon mitigation and round wood production projects. Springer Science + Business Media B.V, Dordrecht, pp 113-114

Ravindranath NH, Somashankar BS, Gadgil M (1997) Carbon flows in Indian forests. Clim Chang 35:297-320.

Richards JF, Flint EP (1994) Historic land use and carbon estimates for South and Southeast Asia 1880-1980. In: ORNL=CDIAC-61, NDP-046. Oak Ridge National Laboratory, Tennessee, p 326.

Rizvi RH, Dhyani SK, Yadav RS, Singh R (2011) Biomass production and carbon stock of poplar agroforestry systems in Yamunanagar and Saharanpur districts of Northwestern India. Curr Sci 100(5):736-742.
Salunkhe O, Khare PK (2016) Aboveground biomass and carbon stock of tropical deciduous forest ecosystems of Madhya Pradesh, India. Int J Ecol Environ Sci 42(S):75-81.

Salunkhe O, Khare PK, Sahu TR, Singh S (2014) Aboveground biomass and carbon stocking in tropical deciduous forests of state of Madhya Pradesh, India. Taiwania 59(4):353-359.

Salunkhe O, Khare PK, Sahu TR, Singh S (2016) Estimation of tree biomass reserve in tropical deciduous forests of Central India by non-destructive approach. Trop Ecol 57(2):153-161.

Segura M, Kanninen M (2005) Allometric models for tree volume and total aboveground biomass in a tropical humid forest in Costa Rica. Biotropica 37:2-8.

Sharma RK, Sankhayan PL, Ole H (2008) Forest biomass density, utilization and production dynamics in a western Himalayan watershed. J For Res 19(3):171-180.

Sharma CM, Gairola S, Baduni NP, Ghildiyal SK, Suyal S (2011) Variation in carbon stocks on different slope aspects in seven major forest types of temperate region of Garhwal Himalaya, India. J Biosci 36(4):701-708.

Sheikh MA, Kumar M, Bussman RW, Todaria NP (2011) Forest carbon stocks and fluxes in physiographic zones of India. Carbon Balance Manag 6:15.

Singh RP (1975) Biomass, nutrient and productivity structure of a stand of dry deciduous forest of Varanasi. Trop Ecol 22:97-105.

Singh KP (1989) Mineral nutrients in tropical deciduous forests savanna ecosystem in India. In: Proctor J (ed) Mineral nutrients in tropical forest and savanna ecosystems. Blackswell Scientific Publications, Oxford, pp 153-158.

Singh J (1990) Nature and distribution of soil humic substances of some plant communities at Ooty, Nilgiri. Myoforestry 26:143-147.

Singh KP, Singh RP (1981) Seasonal variation in biomass, nutrient and productivity structure of a stand of dry deciduous forest of Varanasi. Trop Ecol 16:104-109.

Singh V, Gupta SR, Singh N (2016) Carbon sequestration potential of tropical dry deciduous forests in Southern Haryana, India. Int J Ecol Environ Sci 42(S):51-64.

Subashree K, Sundrapandian S (2017) Biomass and carbon stock assessment in two savannahs of Western Ghats, India. Taiwania 62(3):272-282.

Sundarapandian SM, Amritha S, Gowsalya L, Kayathri P, Thamizharasi M, Dar JA, Srinivas K, Gandhi SD (2013) Estimation of biomass and carbon stock of woody plants in different land-uses. For Res 3:1.

Sundarapandian SM, Amritha S, Gowsalya L, Kayathri P, Thamizharasi M, Dar JA, Srinivas K, Sanjay GD, Subshree D (2014) Biomass and carbon stock assessments of woody vegetation in Pondicherry University campus, Puducherry. Int J Environ Biol 4(2):87-99.

Swami HR (1989) Study of organic productivity, nutrient cycling and small water shade hydrology in natural forests and in monoculture plantations in Chikmagalur district, Karnataka, Final paper, Sri Jagadguru Chandrashekhara Bharti Memorial College, Sringeri, India.

Swami SL, Mishra A (2014) Comparison of biomass and c storage in three promising fast growing tree plantations under agroforestry system in subhumid tropics of Chhattisgarh, India. Uni J Agric Res 2(8):284-296.

Thokchom A, Yadava PS (2017) Biomass and carbon stock along an altitudinal gradient in the forest of Manipur, Northeast India. Trop Ecol 58(2):389-396.

Toky OP, Ramakrishnan PS (1982) Secondary succession subsequent to slash and burn agriculture (Jhum) at higher elevations of Meghalaya in North-East India, I species diversity, biomass and litter production. In: Ramakrishnan PS (ed) Ecological implications of Jhum cultivation on ecosystem functions of subtropical humid forest stands, MAB-project report, vol I. Department of Botany, North East Hill University, Shillong, pp 141-157.

Vashum KT, Jayakumar S (2012) Methods to estimate aboveground biomass and carbon stock in natural forests - a review. J Ecosyst Ecogr 2:116.

Verma A, Tewari A, Shah S (2012) Carbon storage capacity of high altitude Quercus semecarpifolia, forests of Central Himalayan region. Scand J For Res 27:609-618.

Vivek P, Parthasarathy N (2015) Diversity and carbon stock assessment of trees and lianas in tropical dry evergreen forest on the Coromandel Coast of India. Tropl Plant Res 2(3):230-239.

Yadava PS (1986) Ecological studies on forest ecosystem of Manipur, final technical report, action-oriented Himalayan ecodevelopment research project. Department of life sciences, Manipur University, Imphal.

Yavaşli DD (2012) Recent approaches in aboveground biomass estimation methods. Aegean Geogra J 21(1):39-49.

Yoda K (1968) A preliminary survey of the forest vegetation of Eastern Nepal, III plant biomass in the sample plots chosen from different vegetation zones. J Coll Arts Sci Chiba Uni 5:277-302. 